Jurnal Ilmiah Sustainable

Vo. 1. No. 1, Juni 2018, 39-56

\title{
KEPEMIMPINAN TRANSFORMASIONAL PERGURUAN TINGGI ISLAM
}

Oleh:

Agus Triyono, $\mathrm{MBA}^{1}$

\section{Sebuah Perguruan Tinggi Islam di Mata Siswa}

Perguruan tinggi merupakan jenjang pendidikan yang ditempuh oleh siswa untuk meningkatkan kadar keilmuan, wawasan, dan harapan masa depan yang lebih baik. Pilihan perguruan tinggi semakin beragam, terdapat lima jenis perguruan tinggi di Indonesia seperti; Universitas, Institut, Sekolah Tinggi, Politeknik, dan akademi. Sebagian besar siswa memilih universitas yang memiliki banyak program studi yang sangat diminati siswa. Apabila berbicara tentang minat siswa untuk melanjutkan ke perguruan tinggi dipandang dari berbagai faktor seperti pendapatan orang tua, lingkungan, sosial ekonomi, prestasi belajar, dan faktor lainnya, ditemukan bahwa minat siswa SMK, SMA dan sederajat masih tinggi. Faktor-faktor yang terkait dengan minat tersebut telah diteliti oleh Nabila Kharisma dan Lyna Latifah ${ }^{2}$ di Semarang yang menyatakan bahwa prestasi belajar merupakan faktor yang paling berpengaruh terhadap minat siswa melanjutkan ke perguruan tinggi yaitu sebesar $23,91 \%$. Sedangkan menurut Ninuk Indriyanti, Siswandari dan Elvia Ivada ${ }^{3}$ faktor yang paling besar pengaruhnya terhadap minat siswa masuk perguruan tinggi adalah faktor potensi diri sebesar 33,25\%. Indikasi bahwa prestasi belajar dan potensi diri merupakan faktor yang paling berpengaruh terhadap minat siswa untuk melanjutkan ke perguruan tinggi senada dengan pengamatan yang telah dilakukan, siswa-siswa berprestasi lebih besar kecenderungannya untuk membidik perguruan tinggi yang menawarkan dan memiliki program beasiswa dengan berbagai tingkatan nominal. Didapati juga bahwa beasiswa bukan faktor utama yang mempengaruhi minat siswa untuk masuk perguruan tinggi, karena beasiswa baru didapat setelah menyandang status sebagai mahasiswa. Apabila beasiswa tidak lagi didapat, faktor lain akan menjadi faktor penting, seperti orangtua.

\footnotetext{
${ }^{1}$ Penulis adalah Dosen Tetap Jurusan Syariah dan Ekonomi Islam STAIN Syaikh Abdurrahman Siddik Bangka Belitung.

${ }^{2}$ N Kharisma, LL Latifah - Economic Education Analysis Journal, 2015 - journal.unnes.ac.id

${ }^{3}$ N Indriyanti, E Ivada - Jupe-Jurnal Pendidikan Ekonomi, 2013 - jurnal.fkip.uns.ac.id
} 
Jurnal Ilmiah Sustainable

Vo. 1. No. 1, Juni 2018, 39-56

Faktor orang tua juga tidak bisa dipandang sebelah mata, orang tua yang sudah menyadari bahwa masa depan anak juga ditentukan dengan tingkat pendidikan yang bisa di raih akan berusaha mendorong anaknya dan memaksimalkan potensi diri yang dimiliki sang anak untuk mengejar pencapaian tersebut. Tingkat pendidikan orang tua mempengaruhi motivasi orang tua untuk mengantar anaknya ke bangku kuliah. Motivasi yang lebih besar terdapat pada orang tua dengan pendidikan lebih rendah, seperti tingkat SMP dan SMA, dengan acuan alasan agar anaknya tidak akan seperti yang pernah dialaminya. Bagaimana dengan orang tua dengan pendidikan S1 dan seterusnya, motivasi tidak tinggi, hanya keinginan agar anaknya setara dengan orang tua dalam pendidikan, namun lebih mudah mengkondisikan dan memberikan gambaran yang lebih mendekati bagaimana suasana perkuliahan yang akan dijalani anaknya.

Pemaknaan perguruan tinggi oleh siswa dalam peningkatan kadar keilmuan, wawasan dan masa depan juga mengalami peningkatan setelah mendapatkan gambaran dari lingkungan sekitarnya ataupun dari sosialisasi yang dilakukan oleh pihak kampus. Siswa akan melihat bahwa perguruan tinggi merupakan tempat yang tepat untuk meningkatkan ilmu pengetahuan dan potensi diri yang dimilikinya setelah mengetahui apa saja hal yang dapat ditawarkan oleh pihak kampus. Seperti siswa yang tertarik pada bidang akuntansi, akan berusaha mengkolaborasikan antara potensi yang dimilikinya dengan apa yang dapat diberikan oleh pihak kampus. Kondisi ini akan mendorong motivasi siswa kepada tingkat yang lebih tinggi dan mampu menyesuaikan dirinya dengan tingkat kesulitan yang akan dialami. Karena atmosfir SMA sederajat dengan kampus terdapat perbedaan yang cukup signifikan. Saat siswa menjadi mahasiswa, perbedaan sistem dan waktu pembelajaran memaksa mereka untuk menyesuaikan diri dan mengajarkan berbagai hal seperti manajemen waktu, keuangan, konflik dan perilaku berorganisasi. Kesadaran tentang masa depan yang lebih baik diukur dari tingkat pendidikan yang dapat dicapai, sudah menjadi merambah bidang sosial dan budaya. Siswa yang lingkungan sosialnya terdiri dari individu yang memperoleh kesuksesan karena tingkat pendidikannya akan menambah kesadaran tentang pentingnya pendidikan, bahkan apabila di internal keluarga telah terbentuk budaya kampus, siswa akan tergerak dengan sendirinya.

Perguruan tinggi merupakan salah satu lembaga yang mempersiapkan lulusannya untuk diserap pasar tenaga kerja dan menempati posisi-posisi penting dalam berbagai bidang dengan berbagai komponen pendukung yang dimilikinya. Namun, perguruan tinggi memiliki keunikan kompetensi yang hendak ditanamkan kepada lulusannya, karena kompetensi inilah yang akan membedakan tiap perguruan tinggi. Gambaran ini telah diperoleh siswa dari berbagai media yang bisa aksesnya. sehingga ini merupakan kabar baik dan merupakan pangsa pasar yang besar 
Jurnal Ilmiah Sustainable

Vo. 1. No. 1, Juni 2018, 39-56

bagi perguruan tinggi. Walaupun seperti SMK sudah mempersiapkan lulusannya untuk siap diserap pasar tenaga kerja, ini tidak menyurutkan minta para lulusannya untuk melanjutkan ke jenjang yang lebih tinggi.

Namun bagaimana dengan perguruan tinggi islam ? beberapa perguruan tinggi islam sudah bertransformasi menjadi BLU (Badan Layanan Umum) dan mendirikan program studi umum yang biasanya terdapat di universitas, tentu ini akan menjadi sebuah polemik, dimana mempertaruhkan identitas perguruan tinggi islam dengan prodi-prodi keislaman. Terdapat pilhan yang sulit, antara mempertahankan identitas atau mempertahankan kelangsungan hidup lembaga. Sedangkan perguruan tinggi islam merupakan salah satu kontributor besar dalam kehidupan beragama di Indonesia. Hal ini letak keputusannya bukan berada pada lembaga, tapi pada mahasiswa yang telah memilih perguruan tinggi dan menjalani kehidupan akademik.

Perlu diamati, bagaimana mahasiswa memaknai sebuah perguruan tinggi islam. Perguruan tinggi islam mulai berdiri dengan membuka prodi pendidikan agama islam untuk menanamkan pemahaman keagamaan yang kuat untuk siswa di berbagai jenjang pendidikan, seiring berjalan waktu, PTI membuka prodi yang sesuai dengan kebutuhan lembaga penyerap tenaga kerja. Apabila masyarakat berpendapat bahwa PTI hanya melahirkan guru-guru agama dan dai-dai cerdas, pendapat ini tidak dapat disalahkan sepenuhnya, mengingat sejarah terbentuknya PTI banyak yang dimulai dari pendidikan dan dakwah. Akan terbentuk pandangan-pandangan tentang identitas sebuah perguruan tinggi. Untuk menjadi seorang guru agama, siswa akan berpikir PTI merupakan tempat yang tepat, begitu juga bila hendak menjadi dai atau pendakwah cerdas. Namun, bila hendak menjadi seorang manajer, psikolog, dokter, bankir dan profesi lainnya, siswa akan memilih PTU merupakan piihan yang tepat. Padahal terkait dengan BLU, PTI telah menawarkan berbagai program studi umum yang biasanya terdapat di PTU. Namun, apabila pilihan yang telah dijatuhkan ternyata salah, tidak sedikit mahasiswa aktif pindah program studi bahkan pindah perguruan tinggi lain dengan tidak mengindahkan biaya dan waktu yang telah dikeluarkan dari awal pendaftaran hingga terakhir menjalani perkuliahan.

Memaknai kehadiran sebuah perguruan tinggi tidak semata-mata berada pihak siswa, tetapi juga pada pihak lainnya, seperti masyarakat, pemerintah, perusahaan-perusahaan penyerap tenaga kerja, dan internal perguruan tinggi itu sendiri yang terdiri dari berbagai unsur. Salah satunya adalah pemimpin perguruan tinggi. Bagaimanakah sosok pemimpin yang 
Jurnal Ilmiah Sustainable

Vo. 1. No. 1, Juni 2018, 39-56

ideal untuk sebuah perguruan tinggi islam, mari bermula dari kajian teori tentang kepemimpinan.

\section{Teori-teori Kepemimpinan}

Dalam dari Irawaty A. Kahar ${ }^{4}$, menurut Robbert D Stuart bahwa pemimpin adalah seorang yang diharapkan mempunyai kemampuan untuk mempengaruhi, memberi petunjuk dan juga mampu menentukan individu untuk mencapai tujuan organisasi. Seiring dengan itu James P. Spillane ${ }^{5}$ menyatakan bahwa pemimpin itu agen perubahan dengan kegiatan mempengaruhi orang-orang lebih daripada pengaruh orang-orang tersebut kepadanya

Richard L. Daff ${ }^{6}$ mengemukakan konsep kepepemimpinan dalam satu definisi saja yaitu kepemimpinan adalah merupakan suatu pengaruh hubungan antara pimpinan dan pengikut (followers) yang bermaksud pada perubahan dan hasil nyata yang mencerminkan tujuan bersama" Dari definisi tersebut tercakup tujuh unsur yang esensial dalam kepemimpinan, (1) pemimpin (leader), (2) pengaruh (Influence), (3) pengikut (Follower), (4) maksud (Intention), (5) Tujuan bersama (shared purpose), (6) Perubahan (change), (7) tanggung jawab pribadi (Personal responbility). Pengaruh adalah hubungan timbal balik bukan satu arah antara pemimpin dengan pengikut dengan maksud dan harapan terjadi perubahan yang berarti sebagai hasil dari tujuan bersama. Dari pandangan Daff di atas dapat dipahami bahwa pengaruh tidak dikaitkan dengan unsur kekuasaan maupun paksaan yang dilakukan pemimpin terhadap bawahan. Pemimpin mempengaruhi bawahan dan juga bawahan dapat mempengaruhi pemimpin, malahan menurut Daff pengikut yang baik bukanlah "Yes people" kadangkadang pemimpin yang efektif sama dengan dengan pengikut yang efektif, hanya berbeda dalam memainkan perannya. Kemudian unsur tanggung jawab pribadi dan integritas(personal responbility and integrity) menunjukkan adanya tanggung jawab antara pimpinan dan orang-orang yang ada dalam organisasi harus sama-sama mempunyai tanggung jawab penuh untuk mencapai tujuan. Sedangkan unsur perubahan (change) merupakan hasil

\footnotetext{
${ }^{4}$ Stuart, Robert D. and Barbara B. Morgan. Library and information centre management, USA: Library Unlimited, 2002. dalam Irawaty A. Kahar (2008:23) Konsep Kepemimpinan dalam Perubahan Organisasi (Organizational Change) pada Perpustakaan Perguruan Tinggi Jurnal Studi Perpustakaan dan Informasi, Vol.4, No.1, Juni 2008

${ }^{5}$ Spillane, James p. Distributed leadership, San Francisco: Jossey Bass, 2006. dalam Irawaty A. Kahar (2008:23) Konsep Kepemimpinan dalam Perubahan Organisasi (Organizational Change) pada Perpustakaan Perguruan Tinggi Jurnal Studi Perpustakaan dan Informasi, Vol.4, No.1, Juni 2008

${ }^{6}$ Daff, Richard L, The Leadership Experience. Canada: Thomson, 2005. dalam Irawaty A. Kahar (2008:23) Konsep Kepemimpinan dalam Perubahan Organisasi (Organizational Change) pada Perpustakaan Perguruan Tinggi Jurnal Studi Perpustakaan dan Informasi, Vol.4, No.1, Juni 2008
} 
Jurnal Ilmiah Sustainable

Vo. 1. No. 1, Juni 2018, 39-56

dari pimpinan dan pengikut yang menjadi harapan masa depan dan mereka sama-sama menciptakan perubahan, bukan memelihara status quo. Atau dengan kata lain perubahan adalah gambaran dari tujuan bersama (shared purpose).

Tom Peters dan Nancy Austin dalam Robert Kreitner dan Angelo Kinicki ${ }^{7}$ menggambarkan kepemimpinan berarti visi, pemberian semangat, antusiasme, kasih, kepercayaan, kegairahan, nafsu, obsesi, konsistensi, penggunaan simbol, perhatian sebagaimana diilustrasikan oleh isi kalender seseorang, drama luar dan luar (dan manajemen dari itu), penciptaan para pahlawan pada semua tingkatan, bimbingan, berjalan keliling secara efektif, dan sejumlah hal lainnya. Kepemimpinan harus ada di semua tingkatan organisasi. Kepemimpinan bergantung pada sejuta hal-hal kecil yang dilakukan dengan obsesi, konsistensi, dan kepedulian, tetapi sejuta hal-hal kecil tersebut tidak berarti apa-apa jika tidak ada kepercayaan, visi dan keyakinan dasar. Definisi kepemimpinan ini secara jelas melibatkan lebih dari sekedar menggunakan kekuasaan dan menjalankan wewenang, serta ditampilkan pada tingkatan yang berbeda. Pada tingkat individu, misalnya kepemimpinan memberikan nasehat, bimbingan, inspirasi, dan motivasi. Para pemimpin membangun tim, menciptakan kesatuan, dan menyelesaikan perselisihan di tingkat kelompok. Akhirnya, para pemimpin membangun budaya dan menciptakan perubahan di tingkat organisasi.

Macam-macam gaya kepemimpinan yang dibahas Hasibuan ${ }^{8}$ dan Sutrisno yaitu gaya kepemimpinan instruktif, gaya kepemimpinan konsultatif, gaya kepemimpinan partisipasif, dan gaya kepemimpinan delegatif. Gaya kepemimpinan instruktif yaitu jika kekuasaan atau wewenang sebagian besar tetap berada pada pimpinan, ditandai komunikasi satu arah, pimpinan membatasi peranan bawahan, pimpinan menunjukan bawahan tentang apa, kapan dan bagaimana tugas dikerjakan, pemecahan masalah dan pengambilan keputusan menjadi tanggung jawab pimpinan, pelaksanaan pekerjaan diawasi dengan ketat. Gaya kepemimpinan instruktif, indikatornya : komunikasi satu arah, pimpinan membatasi peranan bawahan, pimpinan menunjukan bawahan tentang apa, kapan dan bagaimana tugas dikerjakan, pemecahan masalah dan pengambilan keputusan menjadi tanggung jawab pimpinan, pelaksanaan pekerjaan diawasi dengan ketat.

Gaya kepemimpinan konsultatif yaitu pemimpin mempunyai sedikit kepercayaan pada bawahan biasanya dalam hal kalau ia membutuhkan informasi, ide, atau pendapat bawahan,

\footnotetext{
${ }^{7}$ Robert Kreitner \& Angelo Kinicki, Perilaku Organisasi (Jakarta:Salemba Empat, 2005), hlm.299.

${ }^{8}$ Hasibuan, Malayu S.P. . (2012). Manajemen Sumber Daya Manusia. Jakarta: Bumi Aksara. HIm 172
} 
Jurnal Ilmiah Sustainable

Vo. 1. No. 1, Juni 2018, 39-56

dan masih menginginkan melakukan pengendalian atas keputusankeputusan yang dibuatnya. Pemimpin bergaya konsultatif ini melakukan motivasi dengan penghargaan dan hukuman yang kebetulan, dan juga berkehendak melakukan partisipasi. Gaya kepemimpinan konsultatif, indikatornya : pimpinan masih memberikan instruksi yang cukup besar, komunikasi dua arah, ada suportif pimpinan, pimpinan mau mendengarkan keluhan, bantuan terhadap bawahan ditingkatkan tetapi pengambilan keputusan tetap pada pimpinan. Gaya kepemimpinan partisipasif yaitu gaya kepemimpinanyang memberikan kesempatan kepada bawahan untuk ikut secara aktif baik mental, spiritual, fisik, maupun materiil dalam kiprahnya di organisasi.

Kepemimpinan partisipatif adalah apabila dalam kepemimpinannya dilakukan dengan cara persuasive, menciptakan kerja sama yang serasi, menumbuhkan loyalitas, dan partisipasi para bawahan. Gaya kepemimpinan partisipasif, indikatornya : pimpinan dan bawahan bersama terlibat pemecahan masalah dan pengambilan keputusan, komunikasi dua arah meningkat, pimpinan mendengarkan keluhan bawahan semakin baik. Sedangkan gaya kepemimpinan delegatif yaitu gaya kepemimpinan yang memberikan pelimpahan tugas dan wewenang kepada bawahannya. Seorang pemimpin tidak mungkin dapat mengerjakan sendiri seluruh pekerjaannya karenaketerbatasan waktu dan keterbatasan kemampuannya. Kepemimpinan delegatif apabila seorang pemimpin mendelegasikan wewenang kepada bawahan dengan agak lengkap. Dengan demikian, bawahan dapat mengambil keputusan dan kebijaksanaan dengan bebas atau leluasa dalam melaksanakan kepercayaannya. Gaya kepemimpinan delegatif, indikatornya : pemimpin mendiskusikan masalah yang dihadapi dengan bawahan selanjutnya mendelegasikan pengambilan keputusan seluruhnya pada bawahan, bawahan diberi hak untuk menentukan langkah keputusan dilaksanakan, bawahan diberi wewenang untuk menyelesaikan tugas sesuai keputusanya.

figur pemimpin dapat dilihat dari 8 tipe kepemimpinan menurut Kartini Kartono ${ }^{9}$ :

1. Kharismatis

Hingga kini para pakar belum berhasil menemukan sebab- sebab mengapa seorang pemimpin memiliki kharisma, yang diketahui adalah bahwa pemimpin yang demikian mempunyai daya tarik yang amat besar dan karenanya pada umumnya mempunyai pengikut yang jumlahnya sangat besar. Karena kurangnya pengetahuan tentang sebab

\footnotetext{
${ }^{9}$ Kartini dan Kartono (1983)
} 
musabab seorang menjadi pemimpin yang kharismatis, maka sering dikatakan bahwa pemimpin yang demikian diberkahi dengan kekuatan gaib (supernatural powers).

2. Paternalistis dan Maternatilistis

Yaitu seorang pemimpin yang menganggap bawahannya sebagai manusia yang tidak dewasa, bersikap terlalu melindungi, jarang memberikan kesempatan kepada bawahannya untuk mengambil keputusan dan inisiatif, jarang memberikan kesempatan kepada bawahannya untuk mengembangkan daya kreasi dan fantasinya, sering bersikap maha tahu

3. Militeristis

Yaitu seorang pemimpin yang bertipe militeristis adalah seorang pemimpin yang memiliki sifat- sifat sering mempergunakan sistem perintah dalam menggerakkan bawahannya, senang bergantung pada pangkat dan jabatan dalam menggerakkan bawahannya, senang kepada formalitas yang berlebih- lebihan, menuntut disiplin yang tinggi dan kaku dari bawahan, sukar menerima kritikkan dari bawahan, menggemari upacara- upacara untuk berbagai acara dan keadaan

4. Otokratis

Yaitu seorang pemimpin yang otokratis adalah seorang pemimpin yang menganggap organisasi sebagai milik pribadi, mengidentikan tujuan pribadi dengan tujuan organisasi, menganggap bawahan sebagai alat semata- mata, tidak mau menerima kritik, saran, dan pendapat, terlalu bergantung kepada kekuasaan formalnya, dalam tindakan penggerakannya sering mempergunakan pendekatan yang mengandung unsur paksaan dan punitif (bersifat menghukum)

5. Laissez faire

Yaitu seorang yang bersifat dalam memimpin organisasi biasanya mempunyai sikap yang permisif, dalam arti bahwa para anggota organisasi boleh saja bertindak sesuai dengan keyakinan dan hati nurani, asal kepentingan bersama tetap terjaga dan tujuan organisai tetap tercapai, organisasi akan berjalan lancar dengan sendirinya karena para anggota organisasi terdiri dari orang- orang yang sudah dewasa yang mengetahui apa yang menjadi tujuan organisasi, sasaran yang dicapai, dan tugas yang harus dilaksanakan oleh masing- masing anggota, seorang pemimpin yang tidak terlalu sering melakukan intervensi dalam kehidupan organisasional, seorang pemimpin yang memiliki peranan pasif dan membiarkan organisasi berjalan dengan sendirinya 
Jurnal Ilmiah Sustainable

Vo. 1. No. 1, Juni 2018, 39-56

6. Populistis

7. Administratif

8. Demoktratis

Yaitu tipe yang bersifat dalam proses penggerakkan bawahan selalu bertitik tolak dari pendapat bahwa manusia adalah makhluk termulia di dunia, selalu berusaha mensinkronisasikan kepentingan dan tujuan organisasi dengan kepentingan dan tujuan pribadi dari para bawahannya, senang menerima saran, pendapat bahkan kritik dari bawahannya, selalu berusaha untuk menjadikan bawahannya lebih sukses dari padanya, selalu berusaha mengutamakan kerjasama dan kerja tim dalam usaha mencapai tujuan, berusaha mengembangkan kapasitas diri pribadinya sebagai pemimpin, para bawahannya dilibatkan secara aktif dalam menentukan nasib sendiri melalui peran sertanya dalam proses pengambilan keputusan.

Robert Kreitner dan Angelo Kinicki ${ }^{10}$ membahas juga mengenai kepemimpinan transaksional (transacsional leadership) yang berfokus pada transaksi antarpribadi antara manajer dan karyawan. Pemimpin dipandang sebagai orang yang menggunakan perilaku yang mempertahankan suatu interaksi berkualitas antara diri mereka dengan para pengikutnya. Dua karakteristik yang melandasi kepemimpinan transaksional adalah bahwa (1) para pemimpin menggunakan penghargaan kontinjensi untuk memotivasi para karyawan dan (2) para pemimpin melaksanakan tindakan korektif hanya ketika para bawahan gagal mencapai tujuan kinerja.

Ditambahkan juga oleh Robert Kreitner dan Angelo Kinicki tentang kepemimpinan karismatik yang bertolak belakang dengan kepemimpinan transaksional, kepemimpinan karismatik menekankan perilaku yang simbolis, pesan-pesanmenegani visi dan memberikan inspirasi, komunikasi nonverbal, daya tarik terhadap nilai-nilai ideologis, stimulasi intelektual terhadap para pengikut, serta harapan pemimpin akan pengorbanan diri para pengikut dan untuk kinerja yang melampaui panggilan tugas. Kepemimpinan karismatik dapat menghasilkan perubahan yang signifikan karena mentransformasikan para karyawan untuk mengejar tujuan organisasi di atas kepentingan diri sendiri.

\section{Kepemimpinan Visioner}

${ }^{10}$ Robert Kreitner \& Angelo Kinicki, Perilaku Organisasi (Jakarta:Salemba Empat, 2005), hlm.322. 
Jurnal Ilmiah Sustainable

Vo. 1. No. 1, Juni 2018, 39-56

Pimpinan PT dengan visi yang terlalu tinggi tidak membawa atmosfir yang positif bagi perkembangan lembaga, karena melihat dari kemampuan lembaga yang tidak seiring dengan visi pimpinan, namun bagaimana dengan pimpinan Perguruan tinggi yang tidak mampu menerjemahkan visi ke dalam uraian yang dapat dipahami oleh para jajaran dan bawahannya. Terjemahan visi ini memerlukan dukungan besar dari berbagai komponen perguruan tinggi selain tenaga pendidikan dan kependidikan, dan juga mahasiswa, seperti masyarakat dan pemerintah daerah. Mahasiswa, melihat dari dua sisi kuantitas dan kualitas.

Apakah arti visi, visi11 adalah kemampuan untuk melihat pada inti persoalan, pandangan, wawasan. Sedangkan menurut Mirrian Sjofyan Arif ${ }^{12}$, visi adalah suatu pernyataan yang relatif singkat tentang inspirasi atau arah organisasi yang akan datang berikut dengan alasan-alasannya. Supaya visi ini dapat akurat maka perlu dikaji keadaan dan situasi organisasi sebagai dasar menyatakan visi. Visi harus diumumkan secara luas baik ke dalam organisasi maupun ke luar organisasi dan menyentuh emosi sehingga semua pihak terobsesi untuk mendukungnya.

Kepemimpinan Visioner adalah kemampuan untuk menciptakan dan mengartikulasikan suatu visi yang realistis, dapat dipertanggungjawabkan (credible), visi masa depan yang menarik dan dapat memperbaiki kondisi melebihi situasi sekarang. Pemimpin harus seorang yang visioner, dan dapat berperan sebagai change agent, dapat mengkomunikasikan perubahan baik ke luar maupun ke dalam organisasi, ia harus menguasai teknologi informasi sehingga ia akan dapat bertindak sebagai pelatih dari bawahannya. Kepemimpinan perubahan akan berhasil apabila ia kuat dan mampu menjalankan perannya seperti yang disebutkan di atas, di samping itu beberapa teori menyatakan bahwa kepemimpinan melalui pimpinannya berpengaruh langsung terhadap perubahan organisasi hal ini sangat mendukung untuk pimpinan tersebut melaksanakan perannya. ${ }^{13}$

Diperlukan kepemimpinan yang lebih kreatif dan inisiatif, membantu dalam pemecahan masalah, mendorong dan menyemangati para dosen, dan mengikuti perubahanperubahan di lingkungannya. Di samping itu diperlukan pemimpin yang inspiratif,

\footnotetext{
${ }^{11}$ Kamus Besar Bahasa Indonesia

12 Mirrian Sjofyan Arif, Manajemen Pemerintahan (Tangerang selatan: Universitas Terbuka, 2013), hlm 1.24

13 Irawaty A. Kahar (2008:23) Konsep Kepemimpinan dalam Perubahan Organisasi (Organizational Change) pada Perpustakaan Perguruan Tinggi Jurnal Studi Perpustakaan dan Informasi, Vol.4, No.1, Juni 2008 hlm 24
} 
Jurnal Ilmiah Sustainable

Vo. 1. No. 1, Juni 2018, 39-56

percara diri, visioner, punya idelialisme yang tinggi, dan mampu berkomunikasi dengan baik guna memperbaiki dan menghasilkan kinerja dosen yang lebih baik. Indikator yang paling kuat sebagai pengukur gaya kepemimpinan adalah rangsangan intelektual. Dalam hal ini pemimpin dalam memimpin yang paling berperan adalah rangsangan intelektual yang tinggi. Temuan ini memberikan makna bahwa pemimpin yang memiliki gaya kepemimpinan cenderung bersahabat, informal, dekat dan memperhatikan bawahan sama dengan mereka serta memberikan nasihat, membantu dan mendukung serta mendorong self development followers serta pemimpin dengan rangsangan intelektual ini merupakan pemimpin yang menggunakan intellectualstimulation untuk menstimulasi extraeffort antar bawahan dan membangkitkan hightened efforts para bawahan. ${ }^{14}$

Pemimpin visioner memandang jauh kedepan terhadap berbagai hal pada perguruan tinggi islam, seperti menjawab perubahan kebutuhan sumber daya manusia global yang dicetak dalam bentuk lulusan-lulusan berdaya saing global. Tidak dapat dihindari, ACFTA yang akan diberlakukan penuh pada tahun 2025, bahkan jauh sebelum itu, tenaga kerja asing dari china telah merambah pasar tenaga kerja di Indonesia. Ancaman bagi perguruan tinggi yang belum siap, bagi perguruan tinggi yang telah siap dengan program-program yang dijalankannya dianggap suatu tantangan. Pergeseran status China sebagai negara industri berimbas pada iklim investasi di Indonesia, China menyiapkan dirinya dengan sarjana-sarjana yang berafiliasi dalam komunitas berdaya saing tinggi. China siap menjual produk-produknya berikut dengan tenaga teknisi instalasi dengan harga pasaran yang lebih murah dan masuk akal dibanding dengan paket harga dari kawasan eropa, jepang, ataupun Amerika. Berbagai komponen biaya produksi berhasil diturunkan China hingga pada tataran efisiensi maksimal agar produk mereka mudah diterima di pasara dunia. Indonesia sebagai pasar potensial hingga saat ini telah meyerap produk-produk dari negara China dalam jumlah yang cukup fantastis, seperti smartphone, yang lebih didominasi buatan negeri bambu ini. Dengan meningkatnya kompetisi dari tingkat lokal hingga global, pimpinan perguruan tinggi tidak bisa lagi bersantai-santai dan memberdayakan sumber dayanya sekedar saja, perguruan tinggi harus beradaptasi, lebih ulet, cekatan, dan fokus pada kebutuhan lulusannya. Tidak lagi melulu memanuhi undangan yang bersifat seremonial saja.

\footnotetext{
14 Pelapina Heriana, wahyudi, h. m. chiar, pengaruh gaya kepemimpinan dan iklimorganisasi terhadap kinerja dosen sekolah tinggi ilmu kesehatan (pontianak) hlm 8
} 
Jurnal Ilmiah Sustainable

Vo. 1. No. 1, Juni 2018, 39-56

\section{Kepemimpinan Collective Collegial}

Pimpinan PT di tingkat universitas dan Institut yang terdiri dari Rektor, wakil rektor, dekan, kepala Biro, dan para kepala Bagian. Sedangkan di tingkat Sekolah Tinggi, Politeknik, dan akademik yang terdiri dari Ketua, wakil ketua, ketua jurusan, dan kepala bagian. Pimpinan PT dari berbagai jenjang dan bidang dalam struktur organisasinya memiliki jalur koordinasi dan perintah. Namun dalam pelaksanaannya merupakan satu kesatuan, karena yang hendak dicapai dan didahulukan adalah kepentingan lembaga. Koordinasi di tingkat pimpinan tidak mudah untuk dilaksanakan, mengingat unsur pimpinan terdiri dari individu-individu yang juga memiliki kepentingan pribadi, dan tidak mudah untuk menyingkirkan kepentingan pribadi tersebut. Prinsip satu kesatuan ini sering kita sebut dengan konsep kepemimpinan colective colegial.

Pimpinan PT beserta pejabat dibawahnya memiliki kewajiban membuat keputusan yang dapat memecahkan masalah, baik masalah administrasi maupun teknis. Keputusan ini harus dipertanggungjawabkan karena akan menimbulkan konsekuensi yang tingkatannya tergantung dengan cakupan pelayanannya. Keputusan ini adalah keputusan bersama, walaupun dikeluarkan oleh wakil pimpinan PT, apabila telah dikonsultasikan dengan pimpinan, ini akan menjadi tanggungjawab bersama di tingkat pimpinan. Saling mendukung akan memberikan atmosfer positif bagi semua pihak di bawah kepemimpinan ataupun lingkungan di luar PT. Namun, hal ini tidak mudah terwujud, figur pemimpin sebagai pemersatu harus muncul dan dapat mengayomi unsur-unsur dibawahnya.

Figur pemersatu harus muncul di level pimpinan terlebih dahulu, yang sering terjadi adalah pimpinan dan wakilnya tidak harmonis, jarang melakukan komunikasi yang bersifat membangun, kehadiran pemimpin sebagai pemersatu tidak akan pernah dirasakan. Malah akan membangun konflik yang dapat berujung pada perpecahan dan kubu-kubu yang akan semakin memperbesar ceruk perbedaan di lingkungan perguruan tinggi. Konflik pada pengelolaan efektif dapat memberikan nuansa positif bagi kemajuan lembaga.

Terdapat sebuah ungkapan yang cukup menggelitik, "Orang yang mengira ia sedang memimpin, tetapi tidak memiliki pengikut, hanyalah seorang yang sedang berjalan-jalan" The 21 Irrefutable Laws of Leadership. ungkapan ini bila direspon secara positif akan menyadarkan pemimpin akan keterlenaannya dalam memimpin hingga kehilangan segalanya, namun bila hal ini disadari dari awal, dan ada proses membangun, sehingga setiap individu dalam perguruan tinggi menyadari betapa besarnya arti kehadiran seorang pemimpin bagi 
Jurnal Ilmiah Sustainable

Vo. 1. No. 1, Juni 2018, 39-56

kamajuan lembaga. Apakah terjadi pada suatu perguruan tinggi, pemimpin merasa dia memiliki banyak pengikut yang loyal kepadanya, padahal pengikutnya hanya mengambil keuntungan dari semua keputusan yang akan dan telah dibuatnya, hingga masa akhir kepemimpinannya tidak ada yang tersisa.

\section{Pendelegasian Wewenang}

Bagaimana dengan pendelegasian ?, pendelegasian pun harus melihat pengetahuan dan kemampuan yang dimiliki bawahan sehingga pendelegasian tepat. Kepercayaan termasuk komponen penting dalam pendelegasian, percaya akan kemampuan dan pengetahuan yang dimiliki bawahan.

Pendelegasian wewenang maksudnya untuk mencegah menumpuknya tugas seorang pemimpin sehingga akan mengganggu kinerjanya dan tidak optimalnya perkembangan ide-ied baru dan kreatif untuk lembaga menghadapi perubahan. Pendelegasian tidak berjalan sebagaimana yang diharapkan karena diiringi dengan pemmbatasan kewenangan dalam pengambilan keputusan, hanya terbatas pada kegiatan-kegiatan rutin, untuk pengambilan keputusan diperlukan koordinasi dengan pemegang wewenang sebenarnya, namun kendala akan muncul, karena biasanya pendelegasian dilakukan karena kesibukan yang menumpuk, sehingga koordinasi pun akan mamakan waktu yang cukup lama. Terdapat beberapa hal yang perlu diperhatikan dalam pendelegasian:

1. Tanggung jawab yang tidak boleh didelegasikan. Mendelegasikan wewenang berarti menciptakan pula suatu tanggung jawab bagi atasan terhadap pelaksanaan tugas tersebut oleh bawahan yang diberi delegasi. Perlu pengawasan akan terselenggaranya tugas yang didelegasikan oleh pimpinan, sehingga dapat menjadi sarana tanggung jawabnya.

2. Hindari subkoordinasi. Berlaku suatu asas, yaitu asas kesatuan komando atau unity of command, bahwa dari siapa seseorang menerima pendelegasian wewenang maka kepadanyalah dia harus mempertanggungjawabkan pelaksanaan tugas tersebut. Olehh karena itu harus dihindari pertanggungjawaban bawahan yang keluar dari jalur komando ini.

3. Wewenang seimbang dengan tanggung jawab. Sering terjadi, wewenang yang diberikan tidak seimbang dengan tanggung jawab yang ditimbulkan. Terdapat batasan wewenang yang diberikan dan dapat merupakan bagian kecil dari 
Jurnal Ilmiah Sustainable

Vo. 1. No. 1, Juni 2018, 39-56

keseluruhan proses pekerjaan, sedangkan tanggungjawab yang ditimbulkan bersifat menyeluruh. Menimbulkan beban bagi bawahan dan frustasi yang tinggi, penolakan terhadap wewenang akan diartikan menolak pekerjaan dan berimbas pada penjenjangan karier. Bila diterima kegagalan sudah berada di depan mata, bagi pemimpin hal seperti ini sebaiknya jangan dilakukan karena tidak baik untuk collegial pemimpin.

Hambatan-hambatan dalam pendelegasian menurut Newman dalam Mirrian Sjofyan Arif ${ }^{15}$, dilihat dari dua sisi, yaitu sisi atasan dan bawahan. Dari sisi atasan, atasan menganggap bahwa dia lebih baik melakukan tugas tersebut daripada orang lain, ketidakmampuan atasan untuk mnyerahkan, kurangnya kepercayaan kepada bawahan, tidak adanya pengawasan yang selektif yang memberikan peringatan terhadap kesulitan yang akan terjadi, dan enggan memberi kesempatan kepada bawahan. Sedangkan dari sisi bawahan, hambatan mental seperti belum dewasa cara berpikirnya, takut dikritik, malas bertanggung jawab, kurang percaya kepada diri sendiri, dan insentif positif yang tidak memuaskan.

Hambatan-hambatan seperti di atas akan menghalangi proses collegial dalam perguruan tinggi. Seperti yang diketahui, pada tingkat pimpinan diberikan beban yang cukup besar hingga pada harmonisasi dengan lembaga lainhya, tentunya ini akan mengurangi intensitas kehadiran pimpinan, akan menghambat operasional lembaga.

\section{Perbaikan Kearah Masa Depan yang Gemilang}

Perbaikan lembaga demi masa depan lembaga yang gemilang bukan hanya sebuah wacana, namun dapat direalisasikan dengan menitikberatkan pada kepemimpinan. Menerapkan sebuah gaya kepemimpinan memang bukan hal yang mudah, apalagi setiap pemimpin memiliki gayanya masing-masing. Tetapi dengan mengedepankan kepentingan lembaga di atas ego dapat memberikan perubahan dan perbaikan yang signifikan demi masa depan lembaga. Seperti yang di sampaikan oleh Robert Greenleaf ${ }^{16}$ pada tahun 1970 mencetuskan Kepemimpinan pelayan, greenleaf percaya bahwa para pemimpin besar bertindak sebagai pelayan, mengutamakan kebutuhan orang lain, termasuk para karyawan, pelanggan, dan komunitas, sebagai prioritas pertama mereka. Kepemimpinan pelayan

\footnotetext{
15 Mirrian Sjofyan Arif, Manajemen Pemerintahan (Tangerang selatan: Universitas Terbuka, 2013), hlm 4.47

${ }^{16}$ Robert Kreitner \& Angelo Kinicki, Perilaku Organisasi (Jakarta:Salemba Empat, 2005), hlm.335-336.
} 
Jurnal Ilmiah Sustainable

Vo. 1. No. 1, Juni 2018, 39-56

berfokus pada peningkatan pelayanan bagi orang lain dan bukannya bagi diri sendiri. Terdapat 10 karakteristik kepemimpinan pelayan, namun akan dibahas hanya pada 6(enam) karakteristik yang dapat menjadi sumber renungan dan rujukan bagi pemimpin di sebuah Perguruan Tinggi Islam; (1) mendengarkan, (2) empati, (3) memulihkan, (4) konseptualisasi, (5) pengurusan, dan (6) komitmen pada pertumbuhan orang lain.

Pada karakteristik mendengarkan, pemimpin pelayan berfokus pada mendengarkan untuk mengidentifikasikan dan mengkalirifikasikan kebutuhan dan keinginan dari suatu kelompok, cukup sulit untuk memiliki karakter apabila mendengarkan hanya untuk mengidentifikasi tapi tidak berupaya mengklarifikasi keinginan suatu kelompok. Karakteristik empati, mencoba untuk berempati dengan perasaan dan emosi orang lain. Maksud baik seseorang dianggap ada bahkan ketika orang tersebut berkinerja buruk. Ada kalanya seseorang dalam kondisi bad performance dikarenakan berbagai faktor, seperti masalah keluarga, keuangan, lingkungan kerja yang tidak nyaman, tidak adanya dukungan dari pimpinan, dan kahadirannya sudah diabaikan oleh pimpinan. Kehadiran pimpinan dalam bentuk dukungan agar bekerja lebih baik dan sekedar menyapa para bawahannya dapat memberikan stimulasi yang bagus. Karakteristik memulihkan, pemimpin pelayan berjuang untuk membuat diri mereka sendiri dan orang lain utuh dalam menghadapi kegagalan atau penderitaan. Suatu kegiatan tidak selalu berujung kesuksesan, tapi juga bisa berujung kegagalan, suatu kewajaran kegagalan terjadi apabila tidak dipersiapkan secara matang, namun dapat terjadi suatu hal yang di luar perkiraan. Menyikapi suatu kegagalan sebagai pembelajaran memang sulit untuk dilakukan, namun itu adalah sebuah proses menuju kesuksesan. Kemampuan untuk menerima kegagalan merupakan bagian dari karakter seorang pemimpin. Kegagalan tidak selalu berada pada kesalahan bawahan, seorang pemimpin yang tidak memberikan instruksi dan memberikan menyerahkan pelaksanaan kepada bawahan, dan saat tidak sesuai ekspektasinya, dianggap gagal karena tidak memiliki kemampuan berkreasi. Pekerjaan-pekerjaan teknis memerlukan instruksi yang sistematis dan prosedural, dituntut bawahan untuk memahami instruksi ini, juga dibutuhkan pemimpin yang memiliki pengetahuan dibidang teknis sehingga dapat mengarahkan para bawahannya.

Karakteristik konseptualisasi, pemimpin pelayan menggunakan waktu dan usaha utnuk mengembangkan pemikiran konseptual yang berbasis lebih luas. Pemimpin pelayan mencari suatu keseimbangan yang sesuai antara fokus harian jangka pendek, dengan orientasi konseptual jangka panjang. Perumusan pencapaian bermulai dari tujuan lembaga yang 
Jurnal Ilmiah Sustainable

Vo. 1. No. 1, Juni 2018, 39-56

merupakan terjemahan dari visi dan misi, konsep-konsep dasar merupakan pijakan untuk merealisasikan pencapaian, namun harus dipahami terlebih dahulu apa yang hendak dicapai. Sehingga pengukuran kemampuan SDM dan sarana prasarana yang dimiliki berdaya guna maksimal. Fokus capaian jangka pendek merupakan kontribusi penting untuk capaian jangka panjang, monitoring dan evaluasi dilakukan secara efektif. Kegiatan ini akan dilakukan secara berulang hingga ditemukan konsep yang tepat untuk tujuan lembaga. Apabila konsep dibangun diatas khayalan dan impian dengan tidak melihat kemampuan yang dimiliki, maka hanya akan menjadi wacana semata. Pada proses transformasi lembaga, konseptual akan mengalami perubahan signifikan, apabila masih terhanyut dan merasa nyaman proses transformasi tidak akan berjalan lancar, diperlukan akselarasi yang cepat, koordinasi menyeluruh dengan tidak mengabaikan kepentingan bagian-bagian yang akan memberikan kontribusi. Akselarasi yang cepat dan koordinasi menyelruh hanya dapat dilakukan oleh pemimpin yang sudah memahami konsep yang telah dibangun. Sehingga sangat penting bagi seorang pemimpin memahami tujuan lembaga.

Karakteristik pengurusan, pemimpin pelayan berasumsi bahwa mereka adalah pegurus dari orang dan sumber daya yang mereka kelola. Setiap karyawan memiliki job description yang diterima dari awal sejak mereka menerima jabatan yang tawarkan. Berbagai bentuk job description diberikan sesuai dengan bidang pendidikan, kompetensi lainnya, serta added value yang dimilikinya mengacu pada analisis jabatan. Tidak semata-mata pada need assesment, sehingga dapat terjadi penempatan yang sembarang dan pemberdayaan sumber daya akan tidak maksimal. Tentunya ini suatu bentuk pemborosan apabila menempatkan seseorang yang tidak tepat dan hanya mengisi kekosongan, akan menganggu kinerja bagian tersebut dan juga dapat berimbas pada bagian yang lebih luas. Penghambatan pencapaian dapat disumbangkan oleh kondisi ini. Apakah akan terjadi saling menumpahkan kesalahan pada suatu bagian ke bagian yang lain ?, dapat terjadi apabila bagian ini di isi oleh sumber daya yang tidak kompeten dan tidak mau dipersalahkan, sehingga tidak terjadi proses koreksi dan perbaikan yang jelas akan menghambat kinerja lembaga.

Karakteristik komitmen pada pertumbuhan orang, pemimpin pelayan berkomitmen pada orang yang melampaui peran kerja mereka secara langsung. Mereka berkomitmen untuk memelihara lingkungan yang mendorong pertumbuhan pribadi, profesional dan spiritual. Rerkruitmen merupakan proses pengukuran komitmen setiap orang, komitmen untuk mengedepankan kepentingan lembaga, komitmen untuk kepentingan pribadi. 
Jurnal Ilmiah Sustainable

Vo. 1. No. 1, Juni 2018, 39-56

Kepentingan lembaga tidak harus terpenuhi dengan mengabaikan kepentingan-kepentingan pribadi, karena kepentingan pribadi termasuk komponen pemicu motivasi seseorang untuk maju dan berkembang sehingga tidak bisa diabaikan. Setiap orang menginginkan bentuk pertumbuhan yang bagus dalam karier dengan mengandalkan kinerja yang ditunjukkan, namun bagaimana dengan seseorang yang menginginkan pertumbuhan yang bagus tapi dengan tidak menunjukkan kinerja yang bagus bahkan terkesan bermalas-malasan, sumber daya seperti ini selalu ada pada setiap lembaga walaupun dengan persentase yang berbedabeda. Tidak bijak bagi seorang pemimpin langung memutuskan bahwa karyawan seperti ini harus diberhentikan, dapat di tempuh cara-cara lain yang lebih tepat, mungkin kondisi ini disebabkan oleh lingkungan lembaga yang tidak memberikan atmosfir positif bagi pertumbuhan pribadi. Perlu analisis atas permasalahan yang di alami sehingga solusi yang dilakukan tepat dan sumber daya lembaga selalu terjaga. Spiritual dapat dibangun dan menjadi pondasi yang bagus untuk kesadaran karyawan dalam menjaga komitmen. Dalam pembentukan spritual yang diprakarasi lembaga dengan dilakukan secara bersama-sama, saling menghormati, saling menghargai, dan sadar bahwa segala sesuatu yang diperbuat akan mendapat ganjaran, tentunya akan mampu membangkitkan komitmen dan menjaganya pada tataran sesuai harapan lembaga. Peranan pemimpin sebagai yang terdepan juga harus memberi contoh yang dapat direalisasikan, bagaimana komitmen pemimpin pada lembaga dan komitmen pada sumber daya yang dikelolanya.

Lembaga-lembaga yang berorientasi pada pelayanan, seperti perguruan tinggi, dapat menerapkan gaya kepemimpinan pelayan di atas. Berbagai unsur dalam perguruan tinggi hadir untuk memberikan pelayanan kepada mahasiswa dan mengharapkan timbal balik yang dapat mengembangkan perguruan tinggi agar selalu dapat bersaing dengan perguruan tinggi lainnya. Beberapa hal di atas mendorong unsur-unsur seperti pegawai, dosen, maupun tenaga teknis untuk mengedepankan pelayanan kepada mahasiswa dengan mengambil contoh yang telah dilakukan pemimpinnya. Pada bagian akademik, agar mahasiswa lebih mudah mengakses pelayanan, Standar Operasional Prosedur (SOP) harus ada dan aplikatif untuk diterapkan dengan memperhatikan ketersediaan SDM dan sistem yang telah dibangun. Perkembangan teknologi memberikan kontribusi besar untuk kemudahan akses pelayanan, mahasiswa dapat mengakses dengan menggunakan perangkat-perangkat berbasis online. Memang tidak mudah dan murah, tapi apabila telah dilaksanakan akan diperoleh banyak keuntungan dan kemudahan baik dari sisi pengguna maupun penyedia. Berbagai sistem 
Jurnal Ilmiah Sustainable

Vo. 1. No. 1, Juni 2018, 39-56

online akademik dapat dimanfaatkan perguruan tinggi dengan berbagai tingkatan kompensasi, tergantung kebutuhan perguruan tinggi tersebut. Permasalahan jarak dan waktu dapat disederhanakan dengan memanfaatkan sistem online ini.

Pada bagian keuangan, pembayaran SPP mahasiswa sudah dapat dilakukan dengan memanfaatkan jasa perbankan baik yang konvensional maupun syariah. Terdapat beberapa pilihan, seperti fasilitas Automathic Teller Machine (ATM), online banking, dan internet banking yang sangat memudahkan mahasiswa. Mungkin sebagian besar mahasiswa masih terpaku pada transaksional konservatif, dengan menggunakan pelayanan bank interface, hal ini tidak bisa diabaikan dan perguruan tinggi harus memilih bank-bank yang memiliki cabang yang tersebar di banyak tempat. Teknologi yang semakin berkembang juga harus mampu dikuti oleh perguruan tinggi dengan menyediakan perangkat dan aplikasi yang memadai, serta SDM yang kompeten di bidang itu. Perguruan tinggi islam layaknya menggunakan jasa perbankan dengan prinsip Islam, namun terdapat kendala seperti sebaran kantor cabang yang terbatas, aplikasi perbankan yang belum compatible dengan aplikasi keuangan yang dimiliki perguruan tinggi. Kendala ini dapat di atasi, pada umumnya pihak perbankan menawarkan aplkasi keuangan yang dapat dimiliki dan digunakan perguruan tinggi dengan menyesuaikan kebutuhan internal bagian keuangan. Sedangkan dengan sebaran kantor cabang yang terbatas, pihak perbankan pada umumnya menawarkan pembukaan kantor kas yang letaknya di dalam lingkungan perguruan tinggi, serta telah tersedia sistem link dan ATM Bersama yang memungkinkan pengguna/mahasiswa memanfaatkan jasa bank lain untuk melakukan transaksi.

Perbaikan dalam berbagai bidang diatas dapat dilaksanakan tentunya dimulai dengan sebuah komitmen, komitmen ini harus hadir dalam sosok pemimpin perguruan tinggi dan di transfer kepada pihak-pihak dibawahnya. Sebagian besar perguruan tinggi islam telah melaksanakan komitmen tersebut, komitmen untuk memajukan perguruan tinggi dan menempatkan perguruan tinggi islam yang dipimpinnya sejajar dengan perguruan tinggi terkemuka. Tetapi, bagaimana dengan perguruan tinggi di sekitar anda ?, mari berikan dukungan dan kontribusi nyata demi kemajuan dunia pendidikan kita.

\section{DAFTAR PUSTAKA}


Jurnal Ilmiah Sustainable

Vo. 1. No. 1, Juni 2018, 39-56

Danim, Sudarwan. 2004. Motivasi Kepemimpinan dan Efektivitas Kelompok. Jakarta: Rineka Cipta Utama.

Daff, Richard L. 2005. The Leadership Experience. Canada: Thomson.

Hasibuan, Malayu S.P. 2012. Manajemen Sumber Daya Manusia. Jakarta:Bumi Aksara

Heriana, Pelapina, wahyudi, h. m. Chiar. pengaruh gaya kepemimpinan dan iklim organisasi terhadap kinerja dosen Sekolah Tinggi Ilmu Kesehatan (pontianak)

Irawaty A. Kahar. 2008. Konsep Kepemimpinan dalam Perubahan Organisasi (Organizational Change) pada Perpustakaan Perguruan Tinggi Jurnal Studi Perpustakaan dan Informasi, Vol.4, No.1, Juni 2008

Gill, A, et al. 2010. The Relationship Between Transformasional Leadership and Employee Desire for Empowerment. International Journal of Contemporary Hospitally Management, Vol 22 No 2.

Kartono, Kartini. 1983. Pemimpin dan Kepemimpinan. Jakarta: Rajawali.

Mirrian Sjofyan Arif. 2013. Manajemen Pemerintahan. Tangerang selatan: Universitas Terbuka

N Kharisma, L Latifah. 2015. Economic Education Analysis Journal, - journal.unnes.ac.id

N Indriyanti, E Ivada. 2013. Jupe-Jurnal Pendidikan Ekonomi. - jurnal.fkip.uns.ac.id

O’Leary, Elizabeth. 2001. Kepemimpinan. Edisi Pertama. Yogyakarta: Andi.

Robert Kreitner \& Angelo Kinicki. 2005. Perilaku Organisasi. Jakarta:Salemba Empat

Robbins dan Judge. 2008. Perilaku Organisasi. Edisi Duabelas. Jakarta: Salemba Empat

Spillane, James p. 2006. Distributed leadership, San Francisco: Jossey Bass.

Stone, G.A. et al. 2004. Transformasional Versus Servant Leadership A Differnce in Leader Focus. The Leadership \& Organization Development Journal, Vol 25 No 4.

Stuart, Robert D. and Barbara B. Morgan. 2002. Library and information centre management, USA: Library Unlimited.

Triantoro, Safaria. 2004. Kepemimpinan. Edisi Pertama. Yogyakarta: Graha Ilmu.

Yukl, Gary. 2010. Kepemimpinan dalam Organisasi. Jakarta: Indeks.

Yun Iswanto, Adie Yusuf. 2015. Manajemen Pemerintahan. Tangerang selatan: Universitas Terbuka

https://nuralfiyahum.wordpress.com 